\title{
TRAUMATIC BRAIN INJURY: PROFILE OF PATIENTS ADMITTED IN A PUBLIC HOSPITAL FROM TERESINA CITY
}

\author{
Trauma cranioencefálico: perfil dos pacientes atendidos em um hospital \\ público de Teresina
}

\section{Trauma cranioencefálico: perfil de los pacientes atendidos en un hospital público de Teresina}

Onédia Naís de Carvalho ${ }^{1}$, Isa Moema de Castro Silva², Magda Rogeria Pereira Viana ${ }^{3}$, Maria Zélia de Araujo Madeira ${ }^{4}$ Adelia Dalva da Silva Oliveira ${ }^{5}$, Ana Raquel Batista de Carvalho ${ }^{6}$

\section{How to cite this article:}

Carvalho ON, Silva IMC, Viana MRP, Madeira MZA, Oliveira ADS, Carvalho ARB. Traumatic brain injury: profile of patients admitted in a public hospital from Teresina city. 2020 jan/dez; 12:946-952. DOI: http:// dx.doi.org/0.9789/2175-5361.rpcfo.v12.6835.

\begin{abstract}
Objective: This study meant to identifying the traumatic brain injury patients' profile in a public hospital of Teresina city, Piauí State, Brazil. Methods: It is a descriptive-exploratory, retrospective and documental study with a quantitative approach, which was performed in a public hospital from Teresina city. Data collection took place from September 2016 to January 2017 by researching medical records based on a developed form. Results: Considering the total number of traumatic brain injury hospitalizations, 5.67\% were mild, $92.67 \%$ were moderate, and $1.67 \%$ were severe injuries. There was a predominance of single males within the age group from 19 to 29 years old, holding at most elementary school education. According to the study results, $19.33 \%$ of the patients died. Conclusion: It was concluded that the traumatic brain injury patients' profile is characterized by a predominance of single males within the age group from 19 to 29 years old, holding at most elementary school education.
\end{abstract}

Descriptors: Traumatic brain injury, nursing, health.

\section{RESUMO:}

Objetivo: Identificar o perfil dos pacientes acometidos com traumatismo cranioencefálico atendidas em um hospital público de Teresina. Método: Estudo descritivo, exploratório, retrospectivo, documental de abordagem quantitativa realizado em um hospital público de Teresina-PI. Os dados foram coletados no período set/out/ de 2016 e janeiro de 2017 por meio de pesquisa nos prontuários através do formulário elaborado pelas pesquisadoras. Resultados: Registraram-se 1603 internações com o diagnóstico de traumatismo

1 Nursing Graduate by the Centro Universitário Uninovafapi (UNINOVAFAPI). Email: onedianais14@hotmail.com

2 Nursing Graduate by the UNINOVAFAPI. Email: isamoemak15@outlook.com

3 Nursing Graduate, MSc in Family Health, Professor at UNINOVAFAPI. Email: magdarogeria@hotmail.com

4 Nursing Graduate, PhD in Medical Sciences, Professor at Universidade Federal do Piauí (UFPI) and UNINOVAFAPI. Email: zeliamadeira15@yahoo.com.br

5 Nursing Graduate, PhD in Public Policy, Head of the Nursing Department at UNINOVAFAPI. Email: aoliveira@uninovafapi.edu.br

6 Nursing Graduate by the UNINOVAFAPI Email: ana.raquel.batista@hotmail.com 
cranioencefálico destes, 5,67\% tiveram traumatismo cranioencefálico leve, $92,67 \%$ moderado e $1,67 \%$ grave. Houve predomínio da faixa etária de 18 a 29 anos, sexo masculino, solteiro e o ensino fundamental. Nesta busca, 19,33\% dos pacientes foram a óbito. Conclusão: Conclui-se que o perfil do paciente acometido por trauma cranioencefálico, no hospital estudado, é caracterizado por um predomínio do sexo masculino com uma faixa etária de 19 a 29 anos, solteiros e com escolaridade de até o ensino fundamental.

Descritores: Trauma Craniano; Enfermagem; Saúde.

\section{RESUMEN}

Objetivo: identificar el perfil de los pacientes acometidos con traumatismo craneoencefálico atendidos en un hospital público de Teresina. Método: Estudio descriptivo, exploratorio, retrospectivo, documental de abordaje cuantitativo realizado en un hospital público de Teresina-PI. Los datos fueron recolectados en el período set / out / de 2016 y enero de 2017 por medio de investigación en los prontuarios a través del formulario elaborado por las investigadoras. Resultados: Se registraron 1603 internaciones con el diagnóstico de traumatismo craneoencefálico de éstos, 5,67\% tuvieron traumatismo craneoencefálico leve, $92,67 \%$ moderado y $1,67 \%$ grave. Se observó predominio del grupo de edad de 18 a 29 años, sexo masculino, soltero y la enseñanza fundamental. En esta búsqueda, el 19,33\% de los pacientes fueron a muerte. Conclusión: Se concluye que el perfil del paciente acometido por trauma craneoencefálico, en el hospital estudiado, se caracteriza por un predominio del sexo masculino con una franja etaria de 19 a 29 años, solteros y con escolaridad de hasta la enseñanza fundamental.

Descriptores: Traumatismos Craneocerebrales; Enfermería; Salud.

\section{INTRODUCTION}

Traumatic Brain Injury (TBI) is one of the main public health problems nowadays, being one of the most important causes of death, as well as physical, mental and neurological disabilities. Such condition deteriorates the quality of life and is surpassed only by stroke. ${ }^{1}$

TBI is any aggression of traumatic order that causes anatomical injury or functional impairment of the scalp, skull, meninges, and encephalon or its vessels. ${ }^{2}$ It can be classified as mild, moderate and severe according to the Glasgow coma scale, in which it is accepted worldwide since it establishes a simple method to evaluate the criteria for neurological conditions. It is necessary to apply this scale throughout the follow-up treatment. ${ }^{3}$

In terms of gender, the incidence of TBI is more frequent among men and may cause significant changes in certain risk situations. Among the causes of TBI, the most frequent are those directly involved in traffic accidents, followed by physical aggression, falls, and firearm injuries. ${ }^{2}$

The dominant cause of mortality and morbidity among young adults today is car crashes, even though both the number and severity of TBIs in the last 10 years in developed countries there have been decreased due to increased road and occupational safety. It is assumed that by 2020 TBI will become one of the main causes of death and could be considered a silent epidemic. ${ }^{4}$
Mechanical traumas have left irreversible sequelae in thousands of people in Brazil, especially in relation to traffic accidents. Death from traffic accidents increased mostly in the Northeast and North Regions. The Piaui State, which ranked 20th in 2001 with a rate of 15.3 deaths per 100,000 citizens, then moved to fourth place in $2011 .^{5}$

Based on the large number of accidents that occur daily and analyzing the occurrence of deaths by TBI due to external causes, a study is necessary to identify the TBI victims' profile. The study is very important for developing an effective understanding of how health care professionals, especially nurses, should approach and inform TBI patients.

Bearing in mind the aforementioned, this study targeted at identifying the TBI patients' profile admitted in a public hospital from Teresina city, Piauí State, Brazil.

\section{METHODS}

It is a descriptive-exploratory, retrospective and documental study with a quantitative approach, which was performed in a public hospital known for trauma assistance referral and located in Teresina city, Piauí State, Brazil. The study was carried out from September to October 2016, and in January 2017. The study population consisted of TBI victims admitted to the reference hospital in 2015. The sample was comprised of 300 patient records from a total of 1,603 records, having a margin of error of $5 \%$ with $95 \%$ confidence level.

The medical records of TBI patients aged 18 years old or older and admitted to the reference hospital from January to December 2015. The records of patients without TBI or records with incomplete data were excluded.

The TBI patient records from January 2015 to December 2015 were selected using a form developed by the researchers. After that, a database was created using Microsoft Excel, which was later imported into the Statistical Package for the Social Science (SPSS) for statistical analysis.

The ethical aspects of this study are in line with those presented in Resolution No. 466/2012 from the National Health Council of Brazil. This research was approved by the Research Ethics Committee under the Certificado de Apresentação para Apreciação Ética (CAAE) [Certificate of Presentation for Ethical Appreciation] No. 58232616.0.0000.5210 and Legal Opinion No. 1.709.526 on August 31 $1^{\text {st }}, 2016$.

\section{RESULTS}

The collected data were organized in tables and graphs. Table 1 shows the distribution of the 300 participants according to sociodemographic characteristics. The results revealed that there was a relatively high incidence of TBI in males $(80.67 \%)$. Also, $37.67 \%$ of the TBI patients were in the $18-29$ age group, $36.33 \%$ had at most elementary school education, $45.33 \%$ were single, and $38.33 \%$ were 
married. No data about schooling were found in 36\% of the patient records.

Table 1 - Patients' sociodemographic profile $(n=300)$. Teresina city, Piauí State, Brazil, 2015.

\begin{tabular}{|c|c|c|c|}
\hline & & No. & $\%$ \\
\hline \multirow{2}{*}{ Gender } & Male & 242 & 80.67 \\
\hline & Female & 58 & 19.33 \\
\hline \multirow{5}{*}{ Age group } & 18 |---- 30 & 113 & 37.67 \\
\hline & $30 \mid----40$ & 75 & 25.00 \\
\hline & $40 \mid----50$ & 43 & 14.33 \\
\hline & $50 \mid----60$ & 30 & 10.00 \\
\hline & 60 or more & 39 & 13.00 \\
\hline \multirow{6}{*}{ Education } & illiterate & 17 & 5.67 \\
\hline & Elementary school & 109 & 36.33 \\
\hline & High school & 54 & 18.00 \\
\hline & Higher Education & 6 & 2.00 \\
\hline & $\begin{array}{l}\text { Incomplete Higher } \\
\text { Education }\end{array}$ & 6 & 2.00 \\
\hline & Uninformed & 108 & 36.00 \\
\hline \multirow{6}{*}{$\begin{array}{l}\text { Marital } \\
\text { status }\end{array}$} & Single & 136 & 45.33 \\
\hline & Married & 115 & 38.33 \\
\hline & Divorced & 11 & 3.67 \\
\hline & Widower & 12 & 4.00 \\
\hline & Concubinage & 21 & 7.00 \\
\hline & Ignored & 5 & 1.67 \\
\hline
\end{tabular}

Source: Serviço de Arquivo Médico e Estatística (SAME) [Medical Archive and Statistics Service], Hospital de Urgência de Teresina (HUT), 2016/2017.
Table 2 shows the victims' TBI degree according to gender, age, marital status, education, types of pre-hospital transports, patient's condition, and vehicle used. According to the results, $80.67 \%$ of the patients were male and most of them $(80.58 \%)$ had moderate TBI. Mild TBI affected $82.35 \%$ of the male victims.

Concerning the patients' education level, it was observed that $36.69 \%$ of the patients who had until elementary school education were affected by moderate TBI. There was a predominance of moderate TBI in the 18-29 age group (37.41\%). Regarding the marital status, there was a predominance of single patients suffering from moderate TBI (45.32\%).

Observing the pre-hospital transports, it was observed that the vehicles from the Serviço de Atendimento Móvel de Urgência (SAMU) [Mobile Emergency Care Service] were the most used (50\%). There was a preponderance of this transportation in patients with all levels of TBI: $58.82 \%$ of the mild TBI patients, $49.28 \%$ of the moderate TBI patients, and $60 \%$ of the severe TBI patients. Considering the condition of the patients at the time of the accident, $63.67 \%$ of them were riders, most of them affected by moderate TBI (65.47\%).

When considering all cases in relation to the vehicle used, motorcycles were the most present (75.00\%), being the most prevalent vehicle in all degrees of TBI. It was also observed that information about the use of seat belt and helmet were not found.

Table 2 - Degree of TBI according to gender, age, marital status, education, types of pre-hospital transports, patient's condition and vehicle used $(n=300)$. Teresina city, Piauí State, Brazil, 2015.

\begin{tabular}{|c|c|c|c|c|c|c|c|c|c|}
\hline & & \multicolumn{8}{|c|}{ Degree of TBI } \\
\hline & & \multicolumn{2}{|c|}{ Mild } & \multicolumn{2}{|c|}{ Moderate } & \multicolumn{2}{|c|}{ Severe } & \multicolumn{2}{|c|}{ Total } \\
\hline & & No. & $\%$ & No. & $\%$ & No. & $\%$ & No. & $\%$ \\
\hline \multirow{2}{*}{ Gender } & Male & 14 & 82.35 & 224 & 80.58 & 4 & 80.00 & 242 & 80.67 \\
\hline & Female & 3 & 17.65 & 54 & 19.42 & 1 & 20.00 & 58 & 19.33 \\
\hline \multirow{5}{*}{ Age group } & $18 \mid----30$ & 6 & 35.29 & 104 & 37.41 & 3 & 60.00 & 113 & 37.67 \\
\hline & $30 \mid----40$ & 3 & 17.65 & 72 & 25.90 & - & - & 75 & 25.00 \\
\hline & $40 \mid----50$ & 5 & 29.41 & 37 & 13.31 & 1 & 20.00 & 43 & 14.33 \\
\hline & $50 \mid----60$ & 1 & 5.88 & 28 & 10.07 & 1 & 20.00 & 30 & 10.00 \\
\hline & 60 or more & 2 & 11.76 & 37 & 13.31 & - & - & 39 & 13.00 \\
\hline \multirow{6}{*}{ Education } & Illiterate & 2 & 11.76 & 15 & 5.40 & - & - & 17 & 5.67 \\
\hline & Elementary School & 7 & 41.18 & 102 & 36.69 & - & - & 109 & 36.33 \\
\hline & High School & 4 & 23.53 & 47 & 16.91 & 3 & 60.00 & 54 & 18.00 \\
\hline & $\begin{array}{l}\text { Complete Higher } \\
\text { Education }\end{array}$ & - & - & 6 & 2.16 & - & - & 6 & 2.00 \\
\hline & $\begin{array}{l}\text { Incomplete Higher } \\
\text { Education }\end{array}$ & 1 & 5.88 & 5 & 1.80 & - & - & 6 & 2.00 \\
\hline & Uninformed & 3 & 17.65 & 103 & 37.05 & 2 & 40.00 & 108 & 36.00 \\
\hline
\end{tabular}




\begin{tabular}{|c|c|c|c|c|c|c|c|c|c|}
\hline & & \multicolumn{8}{|c|}{ Degree of TBI } \\
\hline & & \multicolumn{2}{|c|}{ Mild } & \multicolumn{2}{|c|}{ Moderate } & \multicolumn{2}{|c|}{ Severe } & \multicolumn{2}{|c|}{ Total } \\
\hline & & No. & $\%$ & No. & $\%$ & No. & $\%$ & No. & $\%$ \\
\hline \multirow{6}{*}{ Marital status } & Single & 8 & 47.06 & 126 & 45.32 & 2 & 40.00 & 136 & 45.33 \\
\hline & Married & 7 & 41.18 & 106 & 38.13 & 2 & 40.00 & 115 & 38.33 \\
\hline & Divorced & 1 & 5.88 & 10 & 3.60 & - & - & 11 & 3.67 \\
\hline & Widower & - & - & 12 & 4.32 & - & - & 12 & 4.00 \\
\hline & Concubinage & 1 & 5.88 & 19 & 6.83 & 1 & 20.00 & 21 & 7.00 \\
\hline & Ignored & - & - & 5 & 1.80 & - & - & 5 & 1.67 \\
\hline \multirow{5}{*}{ Transportation } & SAMU & 10 & 58.82 & 137 & 49.28 & 3 & 60.00 & 150 & 50.00 \\
\hline & Firefighters & - & - & 6 & 2.16 & - & - & 6 & 2.00 \\
\hline & Does not apply & - & - & - & - & - & - & - & - \\
\hline & Ignored & - & - & - & - & - & - & - & - \\
\hline & Other & 7 & 41.18 & 135 & 48.56 & 2 & 40.00 & 144 & 48.00 \\
\hline \multirow{8}{*}{$\begin{array}{l}\text { Patient } \\
\text { condition }\end{array}$} & Pedestrian & 10 & 58.82 & 35 & 12.59 & - & - & 45 & 15.00 \\
\hline & Motorcyclist & 6 & 35.29 & 182 & 65.47 & 3 & 60.00 & 191 & 63.67 \\
\hline & Passenger & - & - & 21 & 7.55 & - & - & 21 & 7.00 \\
\hline & Cyclist & - & - & 2 & .72 & - & - & 2 & .67 \\
\hline & Driver & - & - & 18 & 6.47 & - & - & 18 & 6.00 \\
\hline & Does not apply & 1 & 5.88 & 20 & 7.19 & 2 & 40.00 & 23 & 7.67 \\
\hline & Ignored & - & - & - & - & - & - & - & - \\
\hline & Other & - & - & - & - & - & - & - & - \\
\hline \multirow{10}{*}{$\begin{array}{l}\text { Vehicle } \\
\text { involved }\end{array}$} & Bicycle & - & - & 1 & .36 & - & - & 1 & .33 \\
\hline & Motorcycle & 15 & 88.24 & 207 & 74.46 & 3 & 60.00 & 225 & 75.00 \\
\hline & Car & - & - & 50 & 17.99 & - & - & 50 & 16.67 \\
\hline & Truck & - & - & - & - & - & - & - & - \\
\hline & Bus & 1 & 5.88 & - & - & - & - & 1 & .33 \\
\hline & Train & - & - & - & - & - & - & - & - \\
\hline & Cart & - & - & - & - & - & - & - & - \\
\hline & Does not apply & 1 & 5.88 & 20 & 7.19 & 2 & 40.00 & 23 & 7.67 \\
\hline & Ignored & - & - & - & - & - & - & - & - \\
\hline & Other & - & - & - & - & - & - & - & - \\
\hline
\end{tabular}

Source: SAME, HUT, 2016/2017.

Table 3 shows the patients' need for surgery, the reason for discharge and hospitalization time. It was observed that $71.67 \%$ of the patients did not undergo surgery and $67.33 \%$ were discharged due to improved condition. Concerning the hospitalization time, an average of 8 days was observed, with a maximum time of 181 days and a minimum of 1 day of hospitalization per patient. 
Table 3 - Patient's need for surgery, the reason for discharge and length of stay ( $n=300$ ). Teresina city, Piauí State, Brazil, 2015.

\begin{tabular}{|c|c|c|c|c|c|c|}
\hline & & No. & $\%$ & Average & Maximum & Minimum \\
\hline \multirow{2}{*}{ Need for surgery } & Yes & 85 & 28.33 & & & \\
\hline & No & 215 & 71.67 & & & \\
\hline \multirow{4}{*}{ Reason for discharge } & Improved condition & 202 & 67.33 & & & \\
\hline & Death & 58 & 19.33 & & & \\
\hline & Transference & 35 & 11.67 & & & \\
\hline & Evasion & 5 & 1.67 & & & \\
\hline \multicolumn{2}{|c|}{ Hospitalization period (days) } & & & 8 & 181 & 1 \\
\hline
\end{tabular}

Source: SAME, HUT, 2016/2017.

Figure 1 describes the occurrence of TBI in patients. There was a predominance of moderate TBI (92.67\%), followed by mild TBI (5.67\%).

Figure 1 - TBI severity degree among the patients. Teresina city, Piauí State, Brazil, 2016/2017.

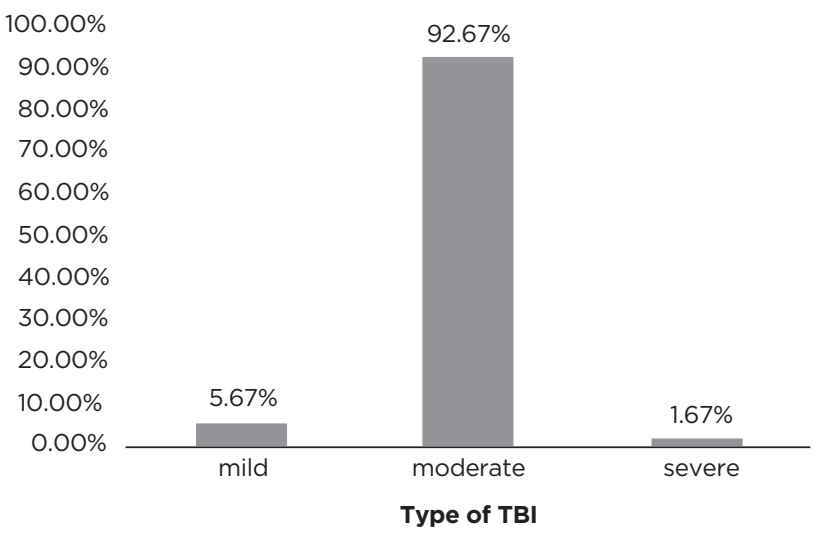

Source: SAME, HUT, 2016/2017.

\section{DISCUSSION}

Table 1 showed a profile of young male patients in productive age, which is in line with several studies. One of these studies showed that, of the total number of victims, $31.45 \%$ were young men in the $21-30$ age group. ${ }^{6}$ The low percentage of women affected by TBI found in this study can be attributed to the fact that men are more exposed to TBI risk factors. ${ }^{7}$

There was a predominance of single patients, followed by married patients. This is supported by a study in which most of the patients were also single $(74.8 \%) .{ }^{8}$ Given the predominance of single and young patients, they end up being the most affected victims in traffic accidents because they are immature, abuse illegal substances, and don't follow traffic laws. ${ }^{9}$

According to this study's results, most patients had at most elementary school education. This is in good agreement with another study in which most patients were people who had less than 8 years of study. ${ }^{10}$ In another study, the percentage of people having elementary school and incomplete high school was the same $(32.3 \%){ }^{8}$

It was possible to extract information on the degree of TBI by analyzing Table 2. There was a predominance of moderate TBI according to the variables gender, age group, marital status and education, contrasting with the results from Table 1 .

The SAMUvehicles were the pre-hospital transportation used by the majority of victims to reach urgency and emergency units regardless of the degrees of TBI. This result contrasts with another in which the hospital ambulance was the most used transportation (60.81\% of the participants). ${ }^{10}$ In another study, the $S A M U$ vehicles were the second most used pre-hospital transportation (11\% of the participants), and vehicles from the Serviço Integrado de Atendimento ao Trauma e Emergência (SIATE) [Trauma and Emergency Care Integrated Service] were used by most of the patients (75\%). ${ }^{11}$ Silva, Galvão and Muraro (2016) showed that the transports most used by victims to reach urgency and emergency units were private $(48.5 \%)$ and SAMU $(34.4 \%)$ vehicles, respectively. ${ }^{12}$

Riders are the most prevalent victims and motorcycles are present in most accidents. Moderate TBI was prevalent in these variables. A study pointed out that motorcycle accidents are the main cause of TBI in $44.55 \%$ of cases. ${ }^{2}$ Another study on TBI caused by car collision and alcoholism in Piaui State, Brazil, showed that the majority of the car crash victims were male (94.5\%). ${ }^{13}$

Most patients were not submitted to surgery in this study, which corroborated with the findings reported on the literature. A study showed that $71.29 \%$ of the patients did not require surgical intervention, while $28.71 \%$ received surgical treatment. ${ }^{2}$ However, other study reported that $80.3 \%$ of the patients were submitted to surgery. ${ }^{14}$

Most TBI victims were discharged from the hospital due to their improved condition, followed by those who died. This fact can be confirmed from a study in which $47.3 \%$ of the patients were discharged due to improved conditions, 
followed by those who were transferred $(31.4 \%) .{ }^{15}$ There was a mortality rate of $19.1 \%$ among hospitalized patients.

The data regarding the hospitalization time in this study were not consistent with the literature. According to a study, most patients (40.1\%) remained hospitalized for 2 to 7 days, with an average time of 15.9 days. ${ }^{15}$ This contrasts with another study, in which the average hospitalization time was 52 days for rehabilitation. ${ }^{8}$

No information concerning the variable use of seat belt and use of helmet were present on the form from the SAMU of Teresina city or on medical records of the patients from Timon city, Maranhão State, Brazil. Using the seat belt reduces by $40 \%$ to $60 \%$ the occurrence of both severe TBI and mortality. Wearing a helmet reduces mortality by $30 \%$. The existence of new protection methods such as airbag and abs brake system may decrease the occurrence of facial injuries, as well as promote a significant reduction in mortality from TBI. ${ }^{16}$

Helmets are an indispensable piece of equipment for the motorcyclists' safety as they reduce the risk and severity of head injury by about $72 \%$ and the probability of death by up to $39 \% .{ }^{17}$ As can be seen in Figure 1, there was a predominance of moderate TBI $(92.67 \%)$, differing from the results reported on the literature. A study revealed that $20 \%$ of the victims had mild TBI, $25.05 \%$ had moderate TBI and $54.2 \%$ had severe TBI according to the Glasgow coma scale. ${ }^{18}$

\section{CONCLUSIONS}

According to this study's results, the profile of the TBI patients is characterized by a predominance of single males within the age group from 19 to 29 years old, holding at most elementary school education.

Motorcycle crashes were the main cause of all types of TBI. The most used pre-hospital transportation was the SAMU vehicle, being prevalent in all levels of TBI. Most patients were discharged due to their improved condition followed by those who died. The average patients' hospitalization time was 8 days, with a predominance of patients with moderate TBI followed by those with mild TBI.

It was possible to observe difficulties in filling out the patients' admission form, which is of paramount importance for analyzing their profile. This data can be used by professionals for more objective and faster decision making.

As a limitation of this study, no information about the use of seat belt and helmet by the TBI victims were recorded by the SAMU of either Teresina or Timon city.
This study meant to informing about the degrees of TBI and making society aware of a large number of hospital admissions due to automobile accidents, in addition to the need for implementing preventive measures.

\section{REFERENCES}

1. Santos F, Casagranda LP, Lange C, Farias JC, Pereira PM, Jardim VMR, Torres AAP. Traumatismo cranioencefálico: causas e perfil das vítimas atendidas no pronto-socorro de Pelotas/Rio Grande do Sul, Brasil. Rev Min Enferm. 2013;17(4):882-7].

2. Moura JC, Rangel BLR, Creôncio SCE, Pernambuco JRB. Perfil clínico- -epidemiológico de traumatismo cranioencefálico do Hospital de Urgências e Traumas no município de Petrolina, estado de Pernambuco. Arq Bras Neurocir 2011; 30:99-104.

3. BRASIL. Ministério da Saúde. Secretaria de Atenção à Saúde. Diretrizes de atenção à reabilitação da pessoa com traumatismo cranioencefálico/ Ministério da Saúde. Secretaria de Atenção à Saúde. Departamento de Ações Programáticas Estratégicas. - Brasília. Ministério da Saúde 2015; 132: il.

4. Oliveira E, Lavrador JP, Santos MM, Antunes JL. Traumatismo crânioencefálico: abordagem integrada. Acta Med Port. 2012; 25:179-92.

5. LOPES, R. D. et al. Perfil epidemiológico dos pacientes acometidos por trauma cranioencefálico assistidos em um Hospital Público de Teresina. Rev. Bras. Neurol. Psiquiatr. 2014; 17(3): 80-90.

6. Albuquerque AMD, Silva HCDL, Maria Barros Torquato I, de Lourdes André Gouveia B, de Almeida Pinto Abrantes M, da silva Ferreira Torres V. MOTORCYCLE ACCIDENT VICTIMS WITH TRAUMA. Journal of Nursing UFPE online. 2016;10(5):1730-38.

7. Morgado F, Rossi L. Correlação entre a escala de coma de Glasgow e os achados de imagem de tomografia computadorizada em pacientes vítimas de traumatismo cranioencefálico. Radiologia Brasileira. 2011;44(1):35-41.

8. Jácomo AAE, Garcia ACF. Análise dos acidentes motociclísticos no Centro de Reabilitação e Readaptação Dr. Henrique Santillo (CRER). Acta Fisiátr. 2011;18(3):124-9.

9. Pedroso AC, Rodrigues CDS. Acidentes de trânsito - perfil epidemiológico de São José do Rio Preto. Arq Ciênc. Saúde. 2012;19(3):51-3.

10. Barros M, Furtado B, Bonfim C. Características clínicas e epidemiológicas de motociclistas com trauma crânio-encefálico atendidos em hospital de referência. Revista Enfermagem UERJ. 2015;23(4).

11. Credo PF, Felix JVC. Perfil dos pacientes atendidos em um hospital de referência ao trauma em Curitiba: implicações para a enfermagem. Cogitare Enferm. 2012;17(1):126-31.

12. Silva HPS, Galvão ND, Muraro AP. PERFIL EPIDEMIOLÓGICO DAS VÍTIMAS DOS ACIDENTES DE TRANSPORTE, REGISTRADOS NOS SERVICOS SENTINELAS DA REDE VIVA NO MUNICÍPIO DE CUIABÁ-MT, 2011. Tempus Actas de Saude Coletiva. 2016; 10(1):95-112.

13. Vale BP, Castro JCD, Araújo MLB, Morais HBD, Macêdo LPD. Traumatismo cranioencefálico por colisão automobilística e alcoolismo no Piauí. Arq Bras Neurocir. 2016. 30(1): 1-8.

14. Sado MJ, Morais FD, Viana FP. Caracterização das vítimas por acidentes motociclísticos internadas no hospital de urgências de Goiânia. Revista Movimenta. 2009; 2(2).

15. Settervall CHC, Sousa RMC. Escala de coma de Glasgow e qualidade de vida pós-trauma cranioencefálico.Acta Paul Enferm. 2012;25(3):364-70 
16. Silva SRA, Araújo MZ, Tacio R, Silva J, Pereira BBM, Medeiros CA

$\mathrm{O}$ traumatismo craniano encefálico moderado e grave. Informativo Técnico do Semiárido. 2015; 9(1): 38-42.

17. Bento MHDS, Neves F, Schmidt AS, Beltrame TF. ATRIBUTOS DA QUALIDADE DE CAPACETE PARA MOTOCICLISTA A PERCEPÇÃO DOS PROFISSIONAIS MOTOFRETISTAS E MOTOTAXISTAS. Rev Ação Ergonimica. 2014; 9(2): 18-33.

18. Passos MSC, Gomes KEP, Pinheiro FGDMS, Paula CLP, Oliveira DML, Sousa Júnior AS. Perfil clínico e sociodemográfico de vítimas de traumatismo cranioencefálico atendidas na área vermelha da emergência de um hospital de referência em trauma em Sergipe. Arq. bras. Neurocir. 2015; 34(4):279-279.

Received in: 15/09/2017

Required revisions: Não houve

Approved in: 14/11/2017

Published in: 01/08/2020

\section{Corresponding author}

Ana Raquel Batista de Carvalho Address: Quadra 45, Renascença II

Teresina/PI, Brazil

Zip code: $64082-550$

Email address: ana.raquel.batista@hotmail.com

Telephone number: +55 (86) 98808-8541

Disclosure: The authors claim to have no conflict of interest. 